Proc. Indian Acad. Sci. (Earth Planet. Sci.), Vol. 92, Number 2. July 1983, pp. 121-128.

(C) Printed in India.

\title{
Recent foraminifers from the inner shelf of the central West Coast, India : A reappraisal using factor analysis
}

\author{
RAJIV NIGAM and JORN THIEDE* \\ National Institute of Oceanography. Dona Paula, Goa 403 004, India \\ * Department of Geology, University of Oslo. P.O. Box 1047, Blindern, Oslo 3, Norway \\ MS received 10 August 1982; revised 4 March 1983
}

\begin{abstract}
Setty and Nigam (1980) had described 72 species of benthonic foraminifers from 25 inner shelf stations off central West Coast of India and the results showed somewhat patchy and anamolous distributions. This paper presents the results of $Q$-mode factor analysis. which was applied to reduce the number of variables into assemblages. The analysis reveals 4 important foraminiferal assemblages, Ammonia beccarii - Ammonia annectens assemblage, Nonion boueanum - Florilus scaphum assemblage. Trochammina inflata assemblage and Bulimina exilis assemblage. They can be related to freshwater run-off and organic matter contents of the sediment.
\end{abstract}

Keywords. Recent foraminifera; factor analysis; inner shelf; central West Coast.

\section{Introduction}

Setty and Nigam (1980) had reported the menthonic foraminifers from the inner shelf area between Dabhol-Vengurla sector of the Arabian Sea and a total of 72 species were recorded from 25 stations. The results showed a somewhat patchy and anamolous distribution of benthonic foraminifers. It was, therefore, found desirable to reduce the number of variables by applying statistical techniques.

This paper presents the results of factor analysis of the foraminiferal data from the central West Coast of India. The other aspects of foraminiferal studies of this region like details of taxon, stationwise distribution of species and ecology, have already been reported (Nigam et al 1979; Setty et al 1979; Setty and Nigam 1980, 1982; Nigam and Sarupria 1981).

Among the various multivariate statistical techniques, factor analysis is a method which can reduce a great number of species to a few assemblages (Imbrie and Van Andel 1964). These assemblages can be plotted to study the geographical distribution and the resulting pattern can be compared to any environmental parameter or group of parameters about which information is available. Factor analyses are being applied extensively to different fields of micropalaeontology e.g.radiolarian studies (Sachs 1973a, b), diatoms (David and Sherwood 1981), Nannoplankton (Geitzenaur et al 1976) and foraminiferal studies (Howarth and Murray 1969; Imbrie and Kipp 1971; Streeter 1972; Thiede 1975). However, no significant attempts have been made to apply this technique to the voluminous collections of foraminiferal data from the Indian region. 


\section{Environmental setting}

The region between Dabhol (Lat. $17^{\circ} 35^{\prime} \mathrm{N}$, Long. $73^{\circ} 06^{\prime} \mathrm{E}$ ) in the north to Vengurla (Lat. $15^{\circ} 50^{\prime} \mathrm{N}$, Long. $73^{\circ} 23^{\prime} \mathrm{E}$ ) in the south is characterised by Shastri and Vashishti in the northern half and Rajapur and Vaghotan rivers in southern half (with several streams and streamlets in between). These rivers and streams are subjected to periodic tidal and seasonal changes, thus where these rivers discharge their load into the sea, dilution of seawater takes place and salinity cannot remain consistent.

The sea floor of the entire study area is covered by clayey substrate except sandy clay at St. No. 3, clayey sand at St. No. 15, silty clay at St. Nos. 16 and 22 and clayey silt at St. No. 27. Organic matter concentrations in terms of percentage in dry sediments ranged from 2.17 to 6.18 (table 1).

\section{Materials and methods}

The data which form the basis of the present study are in the form of percentage counts and have already been published (Setty and Nigam 1980). The samples for this study were collected during March 1977 as a part of the 17th cruise of $R V$ Gaveshani within depth range of $18-51 \mathrm{~m}$ in the sector of the Indian continental shelf between 16 and

Table 1. Texture and organic carbon/matter concentration in sediments within study area.

\begin{tabular}{|c|c|c|c|}
\hline $\begin{array}{l}\text { Station } \\
\text { Number }\end{array}$ & Texture & $\begin{array}{c}\text { Organic carbon } \\
\text { percent } \\
\text { Dry weight }\end{array}$ & $\begin{array}{c}\text { Organic matter } \\
\text { percent } \\
\text { Dry weight }\end{array}$ \\
\hline G 17/1 & Clay & 1.771 & 3.05 \\
\hline 2 & Clay & 1.978 & 3.41 \\
\hline 3 & Clayey sand & 2.162 & 3.73 \\
\hline 5 & Clay & 1.978 & 3.41 \\
\hline 6 & Clay & 1.95 & 3.37 \\
\hline 7 & Clay & 1.84 & 2.17 \\
\hline 8 & Clay & 2.599 & 4.48 \\
\hline 9 & Clay & 3.128 & 5.39 \\
\hline 10 & Clay & 2.99 & 5.15 \\
\hline 12 & Clay & 2.346 & 4.04 \\
\hline 13 & Clay & 2.3 & 3.96 \\
\hline 14 & Clay & 2.806 & 4.84 \\
\hline 15 & Sandy clay & 1.932 & 3.33 \\
\hline 16 & Silty clay & 2.852 & 4.92 \\
\hline 17 & Clay & 2.944 & 5.07 \\
\hline 18 & Clay & 2.024 & 3.49 \\
\hline 19 & Clay & 2.852 & 4.92 \\
\hline 20 & Clay & 3.312 & 5.71 \\
\hline 21 & Clay & 3.358 & 5.79 \\
\hline 22 & Silty clay & 3.22 & 5.55 \\
\hline 23 & Clay & 3.542 & 6.11 \\
\hline 24 & Clay & 3.312 & 5.71 \\
\hline 25 & Clay & 3.036 & 5.23 \\
\hline 26 & Clay & 3.45 & 5.95 \\
\hline 27 & Clayey silt & 3.588 & 6.18 \\
\hline
\end{tabular}

* Organic matter $=$ Organic carbon $\times 1.724$. 
$18^{\circ} \mathrm{N}$. The samples were collected with a Van Veen Grab (area $\left.400 \mathrm{~cm}^{2}\right)$ and La Fond Dietz snapper (area $104 \mathrm{~cm}^{2}$ ). This data subjected to a $Q$-mode factor analysis using Fortran IV program CABFAC (Klovan and Imbrie 1971) was analysed and print-out obtained from the computer centre of University of Oslo. Norway.

\section{Results}

The percentage was initially calculated for all the 72 species from 25 stations. Of these, 24 species occurring rarely within the study area were eliminated from the original matrix and the percentage of all such species was summed for each sample (total not exceeding $4.5 \%$ in any sample). These species were termed 'other species'. A final matrix of 49 variables (48 species + 'other species') was then subjected to $Q$-mode factor analysis. These 6 factors explain almost $93.49 \%$ of the information given by original data matrix. The variance and cumulative variance for these factors is given in table 2. Figure 1 summarises the geographical distribution of various factors/



Figure 1. Sample locations and distribution of assemblages of benthonic foraminifera in the innershelf of Central West Coast, India. $1=$ Ammonia beccarii - Ammonia annectens assemblage; 2 =Nonion boueanum - Florilus scaphum assemblage; $3=$ Trochammina inflata assemblage: $4=$ Bulimina exilis assemblage; $5=$ Ammonia annectens $-A$. beccarii-Nonion boueanum - F. scaphum assemblage; 6= Trochammina globigeriniformis Ammobaculites agglutinans assemblage. 
Table 2. Variance and cumulative variance for each factor.

\begin{tabular}{ccc}
\hline $\begin{array}{l}\text { Factor } \\
\text { number }\end{array}$ & Variance & $\begin{array}{c}\text { Cumulative } \\
\text { variance }\end{array}$ \\
\hline & & \\
1 & 23.247 & 23.247 \\
2 & 22.716 & 45.963 \\
3 & 17.448 & 63.411 \\
4 & 17.130 & 80.541 \\
5 & 8.740 & 89.280 \\
6 & 4.206 & 93.486 \\
\hline
\end{tabular}

assemblages. The boundaries are marked by considering the important factor/factors at every station. Figure 2 shows the contours corresponding to factor-loading at different stations for four important factors/assemblages with reference to depth and location. Varimax factor score matrix (table 3) shows contribution of each species to all factors. The factors a re further described as assemblages and named for one or few common species in each factor as determined from table 3.

Factor 1 (23.7\% of the variance): Ammonia beccarii - Ammonia annectens assemblage.

Factor $2(22.7 \%)$ : Nonion boueanum - Florilus scaphum assemblage.

Factor 3 (17.45\%): Trochammina inflata assemblage.

Factor 4 (17.13\%): Bulimina exilis assemblage.

Factor 5 (8.7\%): Ammonia annectens - Ammonia beccarii-Nonion boueanumFlorilus scaphum assemblage.

Factor 6 (4.2\%): Trochammina globigeriniformis - Ammobaculites agglutinans assemblage.

\section{Discussion}

Ammonia beccarii - Ammonia annectens assemblage is dominated by two species of ammonia viz $A$. beccarii and $A$. annectens. These species are typical for transitional fauna between the marginal-marine and open-marine faunal groups (Walton 1964; Seibold 1971). Ammonia beccarii assemblages are found worldwide in shallow water tropical and temperate areas, particularly those areas influenced by freshwater runoff. Variable environmental conditions including periodic hyposalinity are often mentioned as favourable for this fauna (Boltovskoy and Wright 1976). Hence this assemblage shows mixing of hyposaline water to normal marine water.

Nonion boueanum - Florilus scaphum assemblage is a widely reported assemblage from inner shelf off West Coast of India (Antony 1968; Setty 1974; Setty and Nigam 1980, 1981).

Ammonia annectens - Ammonia beccarii assemblage and Florilus scaphumNonion boueanum assemblage are transitional assemblages showing mixing of freshwater from the nearby rivers to open seawater, but these assemblages are grouped 


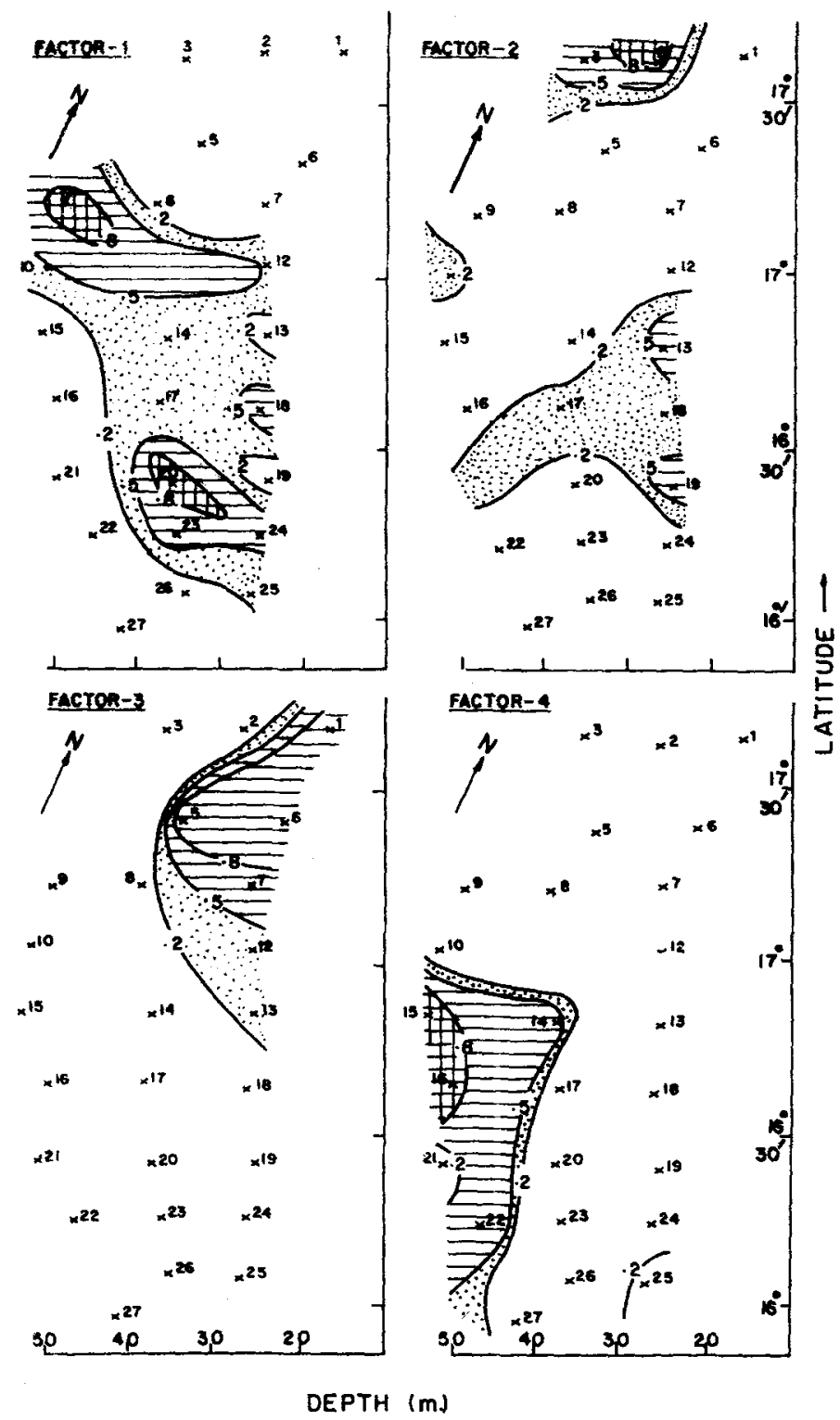

Figure 2. Contours corresponding to factor loading at different stations for four important factors assemblages with reference to depth and location. Factor 1: Ammonia beccarii Ammonia annectens assemblage; Factor 2: Nonion boueanum - Florilus scaphum assemblage; Factor 3: Trochammina inflata assemblage; Factor 4: Bulimina exilis assemblage. 
Table 3. Varimax factor score matrix

\begin{tabular}{|c|c|c|c|c|c|c|}
\hline Species & 1 & 2 & 3 & 4 & 5 & 6 \\
\hline Ammobaculites agglutinans & -0.003 & -0.007 & 0.005 & -0.007 & 0.026 & 0.501 \\
\hline A. dilara & -0.007 & 0.004 & -0.002 & 0.010 & 0.005 & 0.003 \\
\hline Trochammina globigeriniformis & -0.064 & -0.061 & -0.066 & 0.013 & 0.021 & 0.846 \\
\hline T. inflata & 0.110 & 0.18 & -0.985 & 0.006 & -0.041 & -0.043 \\
\hline Eggerella advena & -0.011 & -0.000 & -0.004 & 0.009 & -0.008 & -0.005 \\
\hline E. bradyi & -0.003 & -0.012 & 0.000 & 0.049 & 0.025 & -0.003 \\
\hline Spiroloculina corrugata & -0.005 & 0.006 & 0.002 & -0.003 & 0.007 & -0.001 \\
\hline S. depressa var. rotundata & -0.001 & -0.000 & -0.002 & -0.001 & 0.009 & -0.003 \\
\hline Quingueloculina seminulum & -0.024 & 0.027 & 0.008 & -0.013 & 0.033 & -0.006 \\
\hline Bolivina attica & 0.013 & 0.025 & 0.004 & 0.063 & 0.042 & -0.014 \\
\hline B. lanceolata & 0.005 & -0.024 & -0.000 & 0.064 & 0.002 & -0.009 \\
\hline B. striatula & 0.029 & 0.181 & 0.024 & 0.037 & 0.091 & -0.045 \\
\hline B. subaenariensis & 0.003 & 0.069 & 0.011 & 0.012 & 0.041 & -0.021 \\
\hline Bulimina exilis & 0.051 & -0.187 & 0.012 & 0.889 & 0.100 & 0.018 \\
\hline B. marginata & 0.002 & -0.055 & -0.018 & 0.298 & -0.005 & -0.035 \\
\hline Reussella pacifica & -0.009 & -0.001 & 0.001 & 0.002 & 0.004 & -0.001 \\
\hline Uvigerina senticosa & -0.005 & -0.006 & 0.000 & 0.007 & -0.002 & -0.000 \\
\hline Cancris auricula & 0.006 & -0.017 & 0.001 & 0.063 & -0.006 & -0.009 \\
\hline C. sagara & 0.003 & -0.015 & 0.000 & 0.052 & -0.000 & -0.007 \\
\hline Ammonia annectens & -0.518 & -0.230 & -0.012 & 0.062 & -0.759 & -0.022 \\
\hline A. beccarii & -0.824 & 0.269 & 0.112 & 0.032 & 0.451 & -0.036 \\
\hline A. dentata & -0.008 & 0.083 & 0.019 & 0.003 & -0.023 & -0.012 \\
\hline A. papillosus & -0.073 & 0.001 & 0.035 & 0.010 & -0.106 & -0.009 \\
\hline A. sp. & 0.007 & 0.010 & -0.024 & -0.012 & -0.016 & -0.011 \\
\hline Elphidium falunicum & -0.043 & -0.030 & -0.010 & 0.048 & -0.091 & 0.015 \\
\hline E. indicum & -0.045 & -0.032 & -0.001 & 0.021 & -0.032 & 0.004 \\
\hline E. minutum & 0.004 & 0.040 & 0.006 & 0.023 & 0.005 & -0.006 \\
\hline E. simplex & -0.007 & 0.001 & -0.008 & 0.011 & -0.003 & -0.001 \\
\hline Nummulites ammonoides & 0.007 & -0.004 & -0.020 & 0.005 & -0.004 & -0.004 \\
\hline Eponides repandus & 0.007 & -0.009 & -0.028 & 0.001 & -0.013 & 0.010 \\
\hline Amphistegina radiata & 0.006 & -0.012 & 0.031 & 0.004 & -0.014 & 0.009 \\
\hline Cibicides basiloba & 0.007 & -0.017 & -0.001 & 0.037 & -0.005 & -0.005 \\
\hline C. kullenbergi & 0.001 & -0.007 & -0.000 & 0.014 & -0.002 & -0.002 \\
\hline C. lobalulus & 0.002 & -0.010 & -0.000 & 0.023 & -0.002 & -0.003 \\
\hline C. sp. & 0.006 & -0.005 & -0.002 & -0.000 & -0.011 & -0.002 \\
\hline Fursenkoina pontoni & 0.002 & -0.001 & -0.002 & -0.002 & 0.007 & -0.005 \\
\hline F. sp. & -0.005 & 0.005 & 0.004 & -0.004 & -0.010 & -0.003 \\
\hline Virgulinella pertusa & 0.019 & 0.050 & -0.011 & 0.041 & 0.024 & -0.015 \\
\hline Nonion boueanum & 0.141 & 0.738 & 0.062 & 0.112 & -0.238 & 0.131 \\
\hline N. elongatum & 0.003 & 0.434 & -0.035 & 0.175 & -0.313 & -0.035 \\
\hline N. sp. A. & 0.007 & 0.040 & -0.012 & -0.004 & -0.038 & -0.016 \\
\hline Florilus grateloupi & 0.005 & 0.084 & -0.005 & 0.015 & 0.002 & 0.015 \\
\hline F. scaphum & -0.041 & 0.177 & 0.023 & 0.057 & 0.016 & 0.020 \\
\hline Nonionella basispinata & -0.004 & 0.048 & 0.013 & 0.054 & 0.082 & -0.048 \\
\hline N. auris & 0.007 & 0.036 & 0.009 & 0.096 & 0.051 & -0.027 \\
\hline N. auricula & -0.006 & 0.040 & $0: 009$ & 0.061 & 0.071 & -0.023 \\
\hline N. turgida & -0.006 & 0.013 & 0.008 & 0.041 & 0.019 & -0.014 \\
\hline Other sp. & -0.017 & 0.014 & -0.000 & 0.071 & 0.029 & -0.018 \\
\hline
\end{tabular}


separately. They might be discernible because of their different relationship to organic contents. Total organic matter content varies from $4 \%$ to $6.1 \%$ in factor 1 and $3.4 \%$ to $5.0 \%$ in factor 2 (table 1 ).

Trochammina inflata assemblage is confined to nearshore stations of the northern half of the study area. Because this species is known to occur abundantly in estuarine environment (Bhatia and Kumar 1976), its abundance in the stations near river mouths of Shastri and Vashishti possibly indicating high influx of freshwater. However, stationwise salinity data are not available to check this possibility. The organic matter values are low (3.06\% to $3.37 \%)$ at sample locations where the assemblage is important.

Bulimina exilis assemblage has its maximum loading in stations deeper than $40 \mathrm{~m}$ depths. Bulimina is typically an open-marine fauna with depth range $40-100 \mathrm{~m}$ (Murray 1973). This species prefers to sandy clay and silty clay substrate. Ecologically, this factor seems to be least effected by freshwater run-off. Organic matter values for this factor ranging from $3.3-5.5 \%$.

Ammonia annectens - A. beccarii - Nonion boueanum - Florilus scaphum assemblage has maximum loading at only two stations and assemblage in a mixture of factors 1 and 2 .

Trochammina globigeriniformis - Ammobaculites agglutinans assemblage is dominant at one station only. This factor may have a extension further south of $16^{\circ}$ latitude and showing freshwater influence as both species prefer hyposaline conditions.

In view of their low loading and short geographical distribution, the last two assemblages are less important.

\section{Conclusions}

$Q$-mode factor analysis of 72 foraminiferal species from 25 stations reveals six assemblages within the study area. These assemblages were not apparent in the original data matrix due to the patchy distribution of species. Out of these six, 4 assemblages are prominent. These assemblages can be mapped and compared to any environmental factor or variable for which data are available. In the present study area, factor 3 represents fauna of hyposaline and low organic matter conditions, whereas factor 4 represents a normal marine environment and prefers coarse sediments. Factors 1 and 2 represent transitional fauna indicating mixing of fresh and marine waters. However, organic matter values were relatively high for factor 2 . Factors 5 and 6 are less important as factor 5 is a mixture of factors 1 and 2 and occurs as a major factor at only two stations and factor 6 is confined to only one station.

\section{Acknowledgements}

The authors a re grateful to Dr S Z Qasim and Dr V V R Varadachari for their interest and encouragement. They are also thankful to Shri $H$ N Siddiquie and Dr M G A P Setty for critically going through the manuscript.

\section{References}

Antony A 1968 Bull. Dept. Mar. Biol. Oceanogr. Univ. Kerala, 411

Bhatia S B and Kumar S 1976 /st Int. Symp. Benthonic Foram. Cont. Margin Part A Ecology and Biology,

Maritime Sediment spec. pub. 1239 
Boltovskoy E and Wright R 1976 Recent foraminifera (The Hague: Dr W Jung b.v. - Publisher) 515 David R D and Sherwood W W Jr 1981 Mar. Micropal. 629

Geitzenaur K R, Roche M B and McIntyre A 1976 Geol. Soc, Am. 45423

Howarth R J and Murray J W $1969 \mathrm{~J}$. Palaentol. 43660

Imbrie J and Van Andel T H 1964 Geol. Soc. Am. Bull. 751131

Imbrie J and Kipp N G 1971 In Late Cenozoic glacial ages (ed) K K Turckian (New Haven and London: Yale Univ, Press) 71

Klovan J E and Imbrie J 1971 J. Int. Assoc. Math. Geol. 361

Murray J W 1973 Distribution and ecology of living benthonic foraminiferids (London: Heineman Educational Books) p. 274

Nigam R and Sarupria J S 1981 J. Geol, Soc. India 22175

Nigam R, Setty M G A P and Ambre N V 1979 J. Geol. Soc. India 20244

Sach H M 1973a Quat. Res. 373

Sach H M 1973b Quat. Res. 389

Seibold I 1971 Palaentol. Z. 4541

Setty M G A P 1974 Proc. VI Indian Collog. Micropal. and Stratigr. Varanasi 225

Setty M G A P and Nigam R 1980 Revista Ital. Paleont. 86417

Setty M G A P and Nigam R 1981 Proc. IX Ind. Colloq. Micropal. and Stratigr.. Udaipur (Abstr.) 32

Setty M G A P and Nigam R 1982 Indian J. Mar. Sci. 11225

Setty M G A P. Nigam R and Ambre N V 1979 Mahasagar - Bull. Natn. Inst. Oceanogr. 12195

Streeter S S 1972 Micropal. 1864

Thiede J 1975 Nature (London) 253712

Waiton W R 1964 In Approaches to paleoecology (eds) J Imbrie and N D Newell (New York: John Wiley) p. 151 